\title{
A CONCENTRAÇÃO FUNDIÁRIA COMO UMA DAS FACES DA CONTRARREFORMA AGRÁRIA NO BRASIL: A REPRODUÇÃO DO LATIFÚNDIO E DO MINIFÚNDIO NO CAMPO ALAGOANO
}

\author{
Claudemir Martins Cosme*
Instituto Federal de Alagoas
}

\section{Mônica Cox de Britto Pereira**}

Universidade Federal de Pernambuco

\begin{abstract}
Resumo: Duas indagações resumem as pretensões analíticas deste artigo. A primeira é se, sem alteração na estrutura fundiária concentrada, é possível defender que houve reforma agrária no Brasil. A segunda é como estão a realidade e a dinâmica da estrutura fundiária no campo do estado de Alagoas. Para responder a essas questões, é preciso analisar a estrutura fundiária alagoana de entre 1985 a 2014, objetivo central deste trabalho. A fonte principal de análise são os dados oficiais da estrutura fundiária do Sistema Nacional de Cadastro Rural do Instituto Nacional de Colonização e Reforma Agrária. A reflexão tem por centralidade as contradições da questão agrária brasileira, focando a lente nas especificidades da formação territorial capitalista e no desenvolvimento contraditório do capital no campo do país. Assim, pretendemos demonstrar que a perpetuação da estrutura fundiária concentrada é uma das faces da contrarreforma agrária à moda brasileira e que, em Alagoas, tal processo tem se manifestado na reprodução do latifúndio e do minifúndio como determinante das relações sociais de poder no referido território.

Palavras chave: Estrutura fundiária; Minifúndio; Latifúndio; Campo alagoano.
\end{abstract}

THE LAND CONCENTRATION AS ONE OF THE FACES OF THE AGRARIAN COUNTER REFORMATION IN BRAZIL: THE REPRODUCTION OF LATIFUNDIUM AND SMALLHOLDING IN THE ALAGOANO FIELD

Abstract: Two inquiries summarize the analytical goals of this article: The first one is if without change in the concentrated land structure is possible to argue that there was agrarian reform in Brazil? The second one is: how is the reality and the dynamics of the land structure in the state of Alagoas? In order to answer these questions the main objective of this work is to analyze the Alagoana land structure between 1985 and 2014. The main source of analysis is the official data of the land structure of the National System of Rural Register of the National Institute of Colonization and Agrarian Reform. The Reflection has as its centrality the contradictions of the Brazilian agrarian issue, paying more attention on the specificities of capitalist territorial formation and the contradictory development of capital in the country\&\#39;s countryside. Thus, we intend to demonstrate that the perpetuation of the concentrated land structure is one of the faces of the Brazilian agrarian counterreform, and in Alagoas this process has manifested itself in the reproduction of the latifundium and the smallholding as determinant of the social relations of power in that territory. Key words: Land structure; Smallholding; Latifúndium; Alagoano field.

LA CONCENTRACIÓN AGRARIA COMO UNA DE LAS CARAS DE LA CONTRARREFORMA AGRARIA EN BRASIL: LA REPRODUCCIÓN DEL LATIFUNDIO Y DEL MINIFUNDIO EN EL CAMPO DE ALAGOAS Resumen: Dos preguntas resumen las afirmaciones analíticas de este artículo: sin cambiar la estructura concentrada de la tierra, ¿es posible defender que hubo una reforma agraria en Brasil? ¿Cómo está la realidad y la dinámica de la estructura de la tierra en el campo del estado de Alagoas? Para contestar a estas preguntas, el objetivo principal de este trabajo es analizar la estructura de la tierra en Alagoas, entre 1985 y 2014. La principal fuente de análisis son los datos oficiales de la estructura de la tierra del Sistema Nacional de Registro Rural del Instituto Nacional de Colonización y Reforma Agraria. El foco central de la reflexión son las contradicciones de la cuestión agraria brasileña, enfocando la lente en las especificidades de la formación territorial capitalista y el desarrollo contradictorio del capital en el país. Por lo tanto, tenemos la intención de demostrar que la perpetuación de la estructura de la tierra concentrada es una de las caras de la contrarreforma agraria en la moda brasileña y, en Alagoas, este proceso se ha manifestado en la reproducción del latifundio y del minifundio como determinante de las relaciones sociales de poder en este territorio. Palabras-llave: Estructura agraria; Minifundio; Latifundio; Campo de Alagoas. 
Introdução

Desde os anos 1940 do século XX, discute-se conflituosamente o tema da reforma agrária no Brasil. Nos diferentes contextos políticos, desde a ditadura militar, passando-se pela transição para a Nova República e pelos diferentes governos eleitos, a temática esteve, ora menos, ora mais, presente no debate nacional, produto muito mais da rebeldia e do protagonismo do campesinato e dos diversos grupos explorados do campo, mobilizados em movimentos e organizações sociais, do que da ação propositiva do Estado em buscar solucionar o problema da concentração fundiária.

Durante esse longo período, leis e planos sobre a implementação da reforma agrária vieram se avolumando, bem como, nos discursos dos diferentes governos, há sempre a retórica de que a reforma agrária foi ou está sendo realizada. Nesse contexto, as análises de alguns estudiosos são divergentes. Como comprovação da assertiva, seguem duas transcrições que se contrapõem no âmbito dos estudos geográficos da questão agrária, escritas recentemente: "a via brasileira para realizar a reforma agrária está sendo executada em um processo de longo prazo. Não é uma reforma agrária abrupta, mas uma reforma agrária em frações, determinada pela correlação de forças" (FERNANDES, 2017, p. 248) e "Há anos a reforma agrária é anunciada e não realizada no Brasil, perpetuando o quadro de alta concentração da terra, da renda e da riqueza no campo brasileiro e [...] no conjunto da sociedade [...]" (ALENTEJANO, 2018, p. 309).

Um fato incontestável e que não se pode olvidar nesse debate é o seguinte: o espaço agrário brasileiro do século XXI permanece marcado pela manutenção da profunda desigualdade no acesso, posse e propriedade da terra. Isso fica provado através do Índice de Gini, que demonstra a perpetuação da elevada concentração da terra no campo do país, estacionado na casa de 0,8 (IBGE, 2006) há décadas, mesmo com a construção de milhares de assentamentos rurais. Nesse bojo, duas indagações resumem as pretensões analíticas deste artigo: a) sem alteração na estrutura fundiária concentrada, é possível defender que houve reforma agrária no Brasil?; b) como está a realidade e a dinâmica da estrutura fundiária no campo do estado de Alagoas? A resposta à segunda questão contribuirá para a resposta à primeira.

Destarte, o objetivo central do artigo é analisar a estrutura fundiária brasileira a partir da realidade do campo alagoano no recorte histórico entre 1985 e 2014, e os seus objetivos específicos são: 1) compreender algumas especificidades da formação territorial capitalista brasileira no tocante à reforma agrária; 2) debater como estão estruturados o acesso, a posse e a propriedade da terra no estado de Alagoas; 3 ) refletir sobre a influência da criação dos assentamentos rurais na dinâmica da estrutura fundiária; 4) pôr em relevo as violências e a barbárie promovidas pela burguesia agrária - pelos grandes proprietários de terras - contra os movimentos e organizações sociais do campo, que lutam pela terra e pelo território através da bandeira da reforma agrária.

A construção deste artigo tem como fonte principal os dados oficiais da estrutura fundiária alagoana a partir do Sistema Nacional de Cadastro Rural (SNCR), do Instituto Nacional de Colonização e Reforma Agrária (INCRA), entre os anos de 1985 e 2014, além de pesquisas bibliográficas e dos registros dos relatórios Conflitos no Campo Brasil (1985-2017), da Comissão Pastoral da Terra (CPT). A presente reflexão faz parte de um estudo de doutorado em fase de conclusão sobre a (re)criação do campesinato assentado no sertão alagoano.

Teórico-metodologicamente, no primeiro item, resgatamos o pensamento de Karl Marx (2013) sobre a contradição entre os dois regimes antagônicos de propriedade privada da terra, o "capitalista" e o fundado no "trabalho próprio", para enfatizar o caráter conflituoso e a proteção, quase que absoluta, dada ao primeiro regime em detrimento do segundo, inclusive com a utilização dos métodos da acumulação primitiva violência - na forma abordada por esse autor. Nessa senda, utilizaremos o debate da oposição entre "terra de negócio" e "terra de trabalho" (MARTINS, 1991; DELGADO, 2017), focando a análise à luz das contradições de classes da sociedade brasileira, no seio das suas especificidades históricas, nos termos de Oliveira (2013); Martins $(1991,1999,1981)$ e Oliveira $(2001,2007)$. Por fim, defendemos que o processo da "contrarreforma agrária" analisado por García (1970) se efetiva à moda brasileira, pois a estrutura fundiária concentrada é uma das faces desse processo (CARVALHO, 2014), (re) produzindo o agronegócio enquanto um modelo agrário/ agrícola moderno-colonial no campo brasileiro (BOFF, 2016; PORTO-GONÇALVES, 2012).

No segundo item, abordamos analiticamente a estrutura fundiária alagoana, destacando que existe, espacialmente, pelo menos duas Alagoas a partir da organização e construção do espaço agrário: uma latifundiária, a partir da monocultura da cana-de-açúcar, e outra, minifundiária, onde se reproduz a unidade familiar camponesa. São duas territorialidades conflituosas e que se relacionam, portanto, (re)produzidas dialeticamente em meio a contradições e conflitos entre sujeitos/classes antagônicas, em meio à luta pela reforma agrária e à construção dos assentamentos rurais. Para essa análise, os estudos de Lindoso $(2000,1983)$, Lessa $(2013,2012)$; 
Albuquerque (2016) e Almeida et al. $(2014,2010)$ são basilares. 0 enfrentamento entre o campesinato Sem Terra e as oligarquias latifundiárias alagoanas, na luta pela reforma agrária em meio à violência e à barbárie, é tema do terceiro item, amparado, entre outros, em Porto-Gonçalves e Alentejano (2011), Fernandes (2010) e Neves (1997).

Da terra enquanto um bem comum à sacralização da sua propriedade privada capitalista: a contrarreforma agrária na formação territorial brasileira

A pista inicial que seguimos para compreender a realidade da questão agrária brasileira foi escrita por Marx (2013, p. 786), que, ao abordar o processo que denominou de acumulação primitiva do capital, sublinha a história real da sociedade com relação à questão da constituição da propriedade privada capitalista da terra ao dizer: "[...] o papel principal é desempenhado pela conquista, a subjugação, o assassínio para roubar, em suma, a violência". Enfatiza que "os métodos da acumulação primitiva podem ser qualquer coisa, menos idílicos" (Ibidem, p. 786). Marx se remetia ao perverso processo de expropriação camponesa, ou seja, ao "divórcio", expressão usada por Martins (1991), brutal do campesinato da terra, por isso a afirmação de que se tratava de uma história "[...] gravada nos anais da humanidade com traços de sangue e fogo" (MARX, 2013, p. 787).

Esse pensador deixou, em nossa ótica, uma outra contribuição importante e bastante atual para lermos a questão agrária hoje e o lugar do campesinato sob o modo de produção capitalista, na medida em que enxergou precisamente a diferença entre a propriedade privada capitalista e a propriedade privada fundada no trabalho próprio, afirmando que o segredo era a busca do aniquilamento da segunda pela primeira, conforme a passagem a seguir:

O que nos interessa é apenas o segredo que a economia política do Velho Mundo descobre no Novo Mundo e proclama bem alto, a saber, o de que o modo capitalista de produção e acumulação - e, portanto, a propriedade privada capitalista - exige o aniquilamento da propriedade privada fundada no trabalho próprio, isto é, a expropriação do trabalhador (MARX, 2013, p. 844).

A estrutura fundiária brasileira será construída, histórica e politicamente, como consequência desse embate contraditório de relações de poder entre os sujeitos sociais, que buscaram/buscam, desde 0 processo colonizador-latifundiário-escravista-capitalista até os dias atuais, territorializar esses dois regimes antagônicos de propriedade privada da terra. Nesse sentido, um conjunto de autores, com a lente ajustada para o desenvolvimento contraditório do capital, passou, apesar de compreender a importância explicativa do processo expropriatório descrito por Marx, a defender, concomitantemente, a manutenção das formas não capitalistas ao lado do desenvolvimento da forma capitalista de produção no campo. Nessa esteira, é que a presença constante do campesinato nas diversas sociedades fez Shanin (1983) denominá-lo de "La classe incómoda".

Martins (1999, 1991, 1981), em clara sintonia com a leitura de Marx (2013), através da corrente teórica do desenvolvimento contraditório do capitalismo rentista no país, pôs em relevo a luta do campesinato contra o avanço do capital, seja contra os mecanismos de expulsão/expropriação camponesa da terra; seja contra a subordinação e, com ela, a subjugação da renda da terra. Martins (1991, p. 53) faz a diferenciação do que chama de regimes de propriedade da terra: "de um lado o regime que leva o conflito aos lavradores e trabalhadores rurais, que é o regime de propriedade capitalista; de outro, os regimes de propriedade que têm sido atacados pelo capital, que é o da propriedade familiar [...]". 0 arremate na sua análise, na forma de um apelo importante para a leitura do espaço agrário brasileiro, merece bastante atenção pela atualidade da argumentação: "[...] não podemos confundir a propriedade capitalista com a propriedade familiar, ainda que propriedade privada [...]. A propriedade familiar não é propriedade de quem explora o trabalho de outrem" (MARTINS, 1991, p. 54). Assim, prossegue esse autor:

\footnotetext{
Não é propriedade capitalista; é propriedade do trabalhador. Seus resultados sociais são completamente distintos, porque nesse caso a produção e reprodução das condições de vida dos trabalhadores não é regulada pela necessidade de lucro do capital, porque não se trata de capital no sentido capitalista da palavra (Idem).
}

No cerne dessas contradições, escreve ele, está a terra como um bem comum, visto que a terra é um bem da natureza, e não produto do trabalho, muito menos uma produção do capital. 0 campesinato, segundo Martins (1991), compreende e defende esse princípio, por isso, a defesa da terra é feita como um bem de todos, com a sua posse devendo ser legitimada exclusivamente pelo trabalho. Aí estaria o direito à propriedade privada da terra para os camponeses e camponesas, mas "esse direito está em conflito com os pressupostos da propriedade 
capitalista" (MARTINS, 1991, p. 56). Nessa mesma linha, como analisou Medeiros (2014, p. 26), o acesso à terra é o cerne da questão dos conflitos territoriais no campo, onde as disputas por esse bem "[...] revestiram-se de diversas formas ao longo do tempo, mas sua raiz está no processo de transformação da terra em equivalente de mercadoria e, portanto, na criação de condições para sua livre compra e venda no mercado e apropriação da renda fundiária". Não podemos deixar de visibilizar em nossa leitura, como bem ressaltou essa autora, que "a mercantilização [da terra] subjuga e tende a diluir outros significados dados à terra pelos que nela vivem" (Idem).

Portanto, a contradição histórica entre a "propriedade privada capitalista" e a "propriedade privada fundada no trabalho" (MARX, 2013) foi sempre estruturante dos conflitos territoriais ao longo da produção do território brasileiro, estando no cerne da questão agrária. Recentemente, Delgado (2017, p. 97) trata o tema da questão agrária atualizando o debate aqui proposto, utilizando-se dos conceitos de "terra mercantil" e de "terra bem social", enfatizando que há norma jurídica disciplinadora que busca conciliar os diferentes princípios que regem esses dois regimes de propriedade privada, a saber: "o conceito de função social e ambiental da propriedade". Não obstante, ele ressalta: "mas este conceito constitucional é praticamente desfigurado, em presença de uma nova estratégia de "modernização conservadora" - a economia do agronegócio, que se propõe estabelecer [...] de forma praticamente absoluta - a norma mercantil governando a estrutura agrária" (Idem).

Destarte, a história real da questão agrária brasileira não contada pelos arautos do agronegócio, em uma perspectiva histórica para o campesinato, conforme disse Carvalho (2012, p.1), é que, "nas formações econômicas e sociais dominadas-hegemonizadas pelo modo de produção capitalista têm predominado o desprezo e a discriminação social com relação aos camponeses", não sendo diferente no caso brasileiro. Aliado a isso, destaca Sampaio Jr. (2017, p. 126), perderam-se todas as oportunidades históricas para a realização da reforma agrária ao longo da construção do nosso território: "a vitória definitiva da ala pragmática da burguesia brasileira sepultou de uma vez por todas a possibilidade de uma solução positiva para o problema da terra nos marcos do regime burguês".

Contribuindo com esse autor, o melhor não seria afirmar que as oportunidades foram perdidas, mas que a realização da reforma agrária nunca ocorreu no Brasil devido às forças contrárias a ela, que sempre conseguiram se articular e pôr em dinâmica um processo contrarreformista. Portanto, o que se deu foi uma decisão política do Estado brasileiro, através de diferentes governos nos últimos 70 anos, fruto dos pactos oligárquicos levados a cabo por uma burguesia latifundiária. Para a realização desta discussão, os escritos de García (1970) acerca dos processos de reformas agrárias na América Latina são basilares. 0 autor as classifica em três grandes categorias: reformas agrárias estruturais ou revoluções agrárias, reformas agrárias de tipo convencional sem alterar o estado de coisas vigentes e, por fim, as marginais ou contrarreformas agrárias. Estas últimas resumem-se da seguinte forma:

[...] la de las reformas agrarias marginales, que no apuntan hacia la ruptura del monopolio señorial sobre la tierra o hacia la transformación fundamental de las estructuras latifundistas (relaciones, poder, sistema normativo) sino hacia la reparación superficial de esas estructuras, desviando la presión campesina o la presión nacional sobre la tierra hacia las áreas periféricas y baldías, apoyándose políticamente en el sistema tradicional de partidos y en reglas institucionales de la sociedad tradicional. En razón de orientase este tipo de "reformas" hacia un objetivo estratégico de conservación del statu quo (colonización de áreas periféricas, mejoramiento de tierras, parcelación marginal de latifundios, expansión de la frontera agrícola a la periferia baldía, operación dentro de las normas del mercado tradicional de tierras etc.), su caracterización estricta sería la de contra-reformas agrarias (GARCÍA, 1970, p. 10).

No Brasil, a contrarreforma agrária é um processo histórico. Silva (1971) e lanni (1979) perceberam muito cedo as artimanhas das forças contrarreformistas e as faces dessa contrarreforma, que inviabilizou qualquer alteração na estrutura fundiária nos anos de ditadura militar. Em plenos governos militares, os dois denunciaram a ação do Estado em prol das grandes empresas nacionais e estrangeiras e, consequentemente, a busca da manutenção do latifúndio e do monopólio da terra. A recusa da realização da reforma agrária clássica pela burguesia brasileira, a serviço do avanço do capital no campo, faz ganharem força as interpretações acerca das especificidades da formação territorial capitalista brasileira.

Nesta perspectiva, a crítica de Oliveira (2013 [1972]), realizada há décadas, norteia inicialmente a nossa linha de raciocínio. Esse autor, mesmo entendendo a história da economia brasileira como a expansão de uma economia capitalista, em linhas gerais, defendeu que ela não repete nem reproduz ipsis litteris o modelo clássico do capitalismo central. Parafraseando-o, ao contrário da revolução burguesa clássica, nos anos pós-1930, a 
mudança hegemônica das classes proprietárias rurais pelas novas classes burguesas empresário-industriais não exigirá, no Brasil, uma ruptura total do sistema, não apenas por razões genéticas, mas também por razões estruturais. Outro processo fundamental destacado por Oliveira (2013) foi a expropriação camponesa, que ocorreu de maneira diferente da que houve na Europa. Aqui, não se expropria, absolutamente, a propriedade rural, e sim o excedente produzido.

Em nossa leitura, o excedente é a renda camponesa apropriada no processo de subordinação ao capital, ou seja, apropriada pela burguesia agrária rentista, os grandes proprietários capitalistas da terra. Nessa leitura, os escritos de Martins (1999, 1991, 1981) são fundamentais. Esse autor também ressalta as especificidades da formação social, portanto, da formação territorial brasileira, quando afirma que é preciso considerar que a dissociação entre capital e terra não ocorreu na história brasileira, ocorrendo sim a unificação, no mesmo sujeito social, do latifundiário e do capitalista, formando-se uma classe burguesa latifundista, na qual "o monopólio de classe sobre a terra assegura ao capitalista o direito de cobrar da sociedade inteira um tributo pelo seu uso da terra. É a chamada renda fundiária ou renda da terra" (MARTINS, 1991, p. 55). Martins (1999, p.13) argumenta ainda que "no Brasil a propriedade da terra é o centro de um sistema político persistente. Associada ao capital moderno, deu a esse sistema uma força renovada, que bloqueia tanto a constituição da verdadeira sociedade civil quanto a cidadania de seus membros".

Nesse contexto, a reforma agrária, tida como uma ação clássica para eliminar qualquer empecilho imposto pela propriedade privada da terra à reprodução do capital na agricultura, não foi necessária no Brasil. 0 movimento do capital rentista ocorre, portanto, "[...] primeiro e fundamentalmente pela sujeição da renda territorial ao capital. Comprando a terra, para explorar ou vender, ou subordinando a produção do tipo camponês, o capital mostra-se interessado na sujeição da renda da terra [...]" (MARTINS, 1981, p. 177). No caminho das reflexões acima, está Oliveira (2001), o qual defende que o desenvolvimento capitalista no campo é por si contraditório e desigual, pois avança sujeitando a renda da terra ao capital. Para ele, esse movimento não expande de forma absoluta o trabalho assalariado, mas também cria e recria o trabalho familiar camponês, necessário para a produção do capital.

Almeida (2006), seguindo as sendas abertas por esses dois autores, defende que é insuficiente apenas concluir que o capitalismo, no seu movimento de reprodução ampliada do capital, reproduz relações não capitalistas de produção. Esse pensamento configuraria, segundo ela, um determinismo do capital em detrimento do caráter revolucionário do campesinato. Assim, a luta pela terra no Brasil também (re)cria relações não capitalistas. No caso em estudo pela autora, a luta recria o campesinato assentado. É o desenvolvimento contraditório, desigual, combinado e - é mister ressaltar - conflituoso das diferentes visões de mundo que alicerçam duas formas antagônicas de apropriação privada da terra.

Em meio aos conflitos territoriais, tivemos muitas conquistas camponesas materializadas, como a criação de milhares de assentamentos rurais espacializados no território nacional. Para um conjunto de autores, é a reforma agrária conservadora, parcial, de longo prazo, realizada pelo Estado a reboque dos movimentos e organizações sociais, como dizem Fernandes (2017, 2013) e Sobreiro Filho et al. (2018). Outros estudiosos passaram a evidenciar criticamente a contrarreforma agrária em curso no Brasil, mesmo durante os governos federais Lula da Silva e Dilma Rousseff, ambos do Partido dos Trabalhadores (PT). Era o ranço latifundista que se mantinha nesses governos progressistas com conciliação com o agronegócio (THOMAZ Jr., 2003), contrarreforma que se materializa em diversas faces (COSME, 2017, 2016ab, 2015), desde a legalização da grilagem de terras por parte do Estado (OLIVEIRA, 2010), às leis e à violência/barbárie que impedem sua realização (PORTO-GONÇALVES et al., 2017; PORTO-GONÇALVES e ALENTEJANO, 2011), à expulsão de famílias assentadas causada pela precariedade nos assentamentos rurais (COSME, 2015), às políticas neoliberais de reforma agrária de mercado (RAMOS FILHO, 2012) e, essencialmente, à manutenção da estrutura fundiária concentrada (CARVALHO, 2014).

Assim, assumimos essa última vertente de enxergar a contrarreforma agrária no campo brasileiro. Somente por essa via, a nosso ver, compreenderemos as análises de Boff (2016) de que a sociedade brasileira atual é herdeira de quatro sombras que pesam sobre nós e que originaram e originam a violência: o passado colonial; o genocídio indígena; a escravidão e a Lei de Terras do Brasil, de $n^{\circ} 601$ de 18 de setembro de 1850. 0 histórico processo contrarreformista impediu a remoção dessas sombras e, consequentemente, fez o Brasil do século XXI aprofundar sua questão agrária, com o propalado modelo do agronegócio em detrimento da reforma agrária e da agricultura camponesa. Trata-se de um modelo que se apresenta com uma roupagem moderna, sobretudo economicamente, mas que, no seu cerne, atualiza o que há de mais antigo e colonial nessa formação territorial, ou seja, no tocante ao padrão de poder, estabelece uma forte aliança entre as grandes corporações financeiras 
internacionais, indústrias-laboratórios de agroquímicos e de sementes, cadeias de comercialização e grandes latifúndios exportadores de grãos (PORTO-GONÇALVES, 2012).

No cerne do agrobusiness, portanto, está a concentração fundiária, bem como a busca incessante de subordinar o campesinato que consegue entrar e permanecer na terra. Assim, tem razão Delgado (2017, p. 98) quando defende que, apesar de o novo ciclo da questão agrária e da reforma agrária na atualidade diferir em aspectos históricos com relação aos anos 1960, não difere no essencial: "[...] a inadequação da estrutura agrária estritamente mercantil face às necessidades contemporâneas da vida social, no sentido de regular para "desmercadorizar" a terra". Ainda segundo ele, "os problemas de sua estrutura agrária, que são graves, configuram uma questão agrária nacional" (Ibidem, p. 107). No próximo item, a análise recai justamente sobre essa estrutura fundiária concentrada no caso do campo alagoano.

Concentração fundiária: reprodução do latifúndio e do minifúndio no campo alagoano

Inicialmente, é mister destacar que os conceitos de minifúndio e latifúndio, apesar de banidos dos normativos institucionais do Estado e de execrados no discurso de acadêmicos e políticos defensores do agronegócio na atualidade, são partes de uma nomenclatura a se resgatar e destacar nas análises da questão agrária, pois são conteúdos importantes no debate sobre as contradições entre terra de negócio e terra de trabalho, bem como imprescindíveis para construção de uma efetiva proposta de reforma agrária. Já a Lei $n^{\circ} 4.504$, de 30 de novembro de 1964 (Estatuto da Terra), define o minifúndio como o imóvel rural de área e possibilidades inferiores às da propriedade familiar, e a Lei $n^{\circ} 8.629$, de 25 de fevereiro de 1993, que regulamentou os dispositivos constitucionais relativos à reforma agrária previstos na Constituição de 1988, conceituou, na sua versão inicial ${ }^{1}$, no artigo $4^{\circ}$, a pequena propriedade como sendo aquela que possui área compreendida entre 1 (um) e 4 (quatro) módulos fiscais; a média propriedade como aquela que possui área superior a quatro (4) e até 15 (quinze) módulos fiscais; e a grande propriedade como aquela que compreende mais de 15 módulos fiscais.

Todavia, Mitidiero Junior, Barbosa e Hérick de Sá (2017), em seus estudos sobre a produção agropecuária no campo brasileiro a partir dos dados do Censo

1 Lei que, ao longo dos anos, foi modificada pela bancada ruralista no Congresso Nacional, sob os auspícios dos grandes proprietários de terra, por exemplo, com a retirada do texto da categoria grande propriedade.
Agropecuário do Instituto Brasileiro de Geografia e Estatística (IBGE), destacam que existem várias opções metodológicas no tocante à questão do critério de área. Isso, a nosso ver, é verdadeiro também para o estudo da estrutura fundiária em si. Assim, nos estudos da Geografia Agrária, ainda não há um consenso acerca da melhor forma de classificação das propriedades.

Nessa esteira, antes de adentrarmos na análise dos dados sobre a estrutura fundiária alagoana, é necessária uma breve exposição para explicitarmos a metodologia adotada. Oliveira (2003) trabalhou com três classes de área - pequena, a de até 200 ha; média, a de 200 a 2.000 ha; grande, a de mais de 2.000 ha - quando analisou os dados do IBGE e do INCRA, em uma aproximação com a classificação da pequena, média e grande propriedade presente na Lei Agrária de 1993. Entretanto, o mesmo Oliveira (2001 [1991]) analisou com outra metodologia a estrutura fundiária brasileira e o lugar do campesinato nela, dividindo as três classes de área em menos de 100 ha, de 100 a menos de 1.000 ha e de 1.000 ha acima e reunindo o campesinato no primeiro extrato. Tal proposta fica mais clara em Oliveira (2007).

Mitidiero Junior, Barbosa e Hérick de Sá (2017), seguindo o primeiro trabalho deste autor, adotaram o seguinte critério de classificação: os estabelecimentos rurais que possuem entre 0 a 200 hectares (ha) são considerados pequenos; os que têm de 200 a 1.000 ha são os de médio porte; e os que têm acima de 1.000 ha, são os de grande porte. Além disso, pela necessidade do estudo e em face da realidade brasileira, criaram o estrato de área separado da análise da totalidade dos dados: os estabelecimentos de 0 a 10 ha, intitulados de quase pequenos.

Já Moreira e Targino (1997), analisando a estrutura fundiária paraibana, denominam de pequenas propriedades os estabelecimentos com menos de 50 ha e, em nossa ótica, de médias entre 50 e 500 ha e grandes acima de 500 ha. Ramos Filho e Ramos (2014), em um estudo sobre a estrutura fundiária de Sergipe, seguem a mesma linha de Oliveira (2001) e se aproximam de Moreira e Targino (1997), considerando pequenas as propriedades de até 100 ha, médias as de 100 a menos de 1.000 ha e grandes as de mais de 1000 ha.

Nesse bojo, pautamos nossa análise a partir dos estudos que dividem a estrutura fundiária brasileira da seguinte forma: pequenas propriedades as de até 100 ha, médias propriedades as de 100 a menos de 1.000 ha e grandes propriedades as de mais de 1000 ha. Essa linha, em nossa ótica, está mais próxima da realidade do espaço agrário alagoano, bem como mais sintonizada com uma perspectiva de uma reforma agrária com base na agricultura familiar camponesa. Para tal, levaremos 
em conta que, no contexto alagoano, o módulo fiscal varia de acordo com as zonas naturais de 7 a 70 ha, tendo em média 32 ha; portanto, é nesses termos que destacaremos o processo de minifundização como a outra face, ou melhor, o reverso da estrutura fundiária latifundista nesse estado. Entrementes, salientamos que o debate segue aberto sobre a melhor forma de estratificação das propriedades rurais, inclusive, para uma proposta de reforma agrária. Debate que pretendemos aprofundar em outros estudos a partir da realidade do campo alagoano.

Os dados cadastrais do INCRA apontam que, em 1985, em termos totais, Alagoas tinha 61.437 imóveis rurais. Destes, $0,46 \%$ (284) eram imóveis classificados como grandes propriedades (de mais de $1.000 \mathrm{ha}$ ) e ocupavam 22,84\% (598.522,10 ha) da área total de 2.621.025,50 ha. Analisando a face oposta, ou seja, as pequenas propriedades (de menos de $100 \mathrm{ha}$ ), temos, em $1985,92,44 \%$ (56.795) do número total de imóveis rurais ocupando apenas $33,90 \%(888.501,20 \mathrm{ha})$ da superfície total agricultável declarada. Em 2014, o número total de imóveis cai drasticamente para 48.592, e as grandes propriedades perdem área, mas se mantém o latifúndio, que representa apenas $0,26 \%$ (126 imóveis rurais) e ocupa $13,25 \%$ (227.622,28 ha) da superfície total $(1717.128,22$ ha). Já as pequenas propriedades se mantêm praticamente inalteradas, com 92,94\% (45.163) dos imóveis e com apenas 38,01\% (652.655,25 ha) da área total (ver tabela 1).

Tabela 01: Alagoas - Evolução da Estrutura Fundiária - (1985/2014)

\begin{tabular}{c|c|c|c|c|c|c|c|c}
\hline \multirow{2}{*}{ Classe de área (ha) } & \multicolumn{4}{|c|}{$\mathbf{1 9 8 5}$} & \multicolumn{3}{c|}{$\mathbf{2 0 1 4}$} \\
\cline { 2 - 9 } & $\begin{array}{c}\mathbf{N}^{\circ} \\
\text { Imóveis }\end{array}$ & $\begin{array}{c}\text { \% } \\
\text { Imóveis }\end{array}$ & $\begin{array}{c}\text { Área } \\
\text { (ha) }\end{array}$ & $\begin{array}{c}\text { \% } \\
\text { Área }\end{array}$ & $\begin{array}{c}\mathbf{N}^{\circ} \\
\text { Imóveis }\end{array}$ & $\begin{array}{c}\text { \% } \\
\text { Imóveis }\end{array}$ & $\begin{array}{c}\text { Área } \\
\text { (ha) }\end{array}$ & $\begin{array}{c}\text { \% } \\
\text { Área }\end{array}$ \\
\hline Menos de 10 & 31.185 & 50,76 & $137.869,50$ & 5,26 & 27.668 & 56,94 & $113.070,44$ & 6,58 \\
\hline $10<100$ & 25.610 & 41,68 & $750.631,70$ & 28,64 & 17.495 & 36,00 & $539.584,81$ & 31,42 \\
\hline Total menos 100 & $\mathbf{5 6 . 7 9 5}$ & $\mathbf{9 2 , 4 4}$ & $\mathbf{8 8 8 . 5 0 1 , 2 0}$ & $\mathbf{3 3 , 9 0}$ & $\mathbf{4 5 . 1 6 3}$ & $\mathbf{9 2 , 9 4}$ & $\mathbf{6 5 2 . 6 5 5 , 2 5}$ & $\mathbf{3 8 , 0 1}$ \\
\hline $100<1000$ & 4.358 & 7,09 & $1.134 .002,20$ & 43,27 & 3.303 & 6,80 & $836.850,69$ & 48,74 \\
\hline Mais de 1000 & 284 & 0,46 & $598.522,10$ & 22,84 & 126 & 0,26 & $227.622,28$ & 13,25 \\
\hline Total mais 100 & $\mathbf{4 . 6 4 2}$ & $\mathbf{7 , 5 6}$ & $1.732 .524,30$ & $\mathbf{6 6 , 1 0}$ & $\mathbf{3 . 4 2 9}$ & $\mathbf{7 , 0 6}$ & $\mathbf{1 . 0 6 4 . 4 7 2 , 9 7}$ & $\mathbf{6 1 , 9 9}$ \\
\hline Total geral & $\mathbf{6 1 . 4 3 7}$ & $\mathbf{1 0 0}$ & $\mathbf{2 . 6 2 1 . 0 2 5 , 5 0}$ & 100,00 & $\mathbf{4 8 . 5 9 2}$ & $\mathbf{1 0 0 , 0 0}$ & $\mathbf{1 . 7 1 7 . 1 2 8 , 2 2}$ & $\mathbf{1 0 0 , 0 0}$ \\
\hline
\end{tabular}

Fonte: INCRA (1985; 2014). Organização: Claudemir Martins Cosme.

Fica evidente o processo de concentração fundiária no campo alagoano, a partir da reprodução do latifúndio, em um polo, e, no outro, da reprodução do minifúndio. A minifundização fica mais explícita quando da análise do extrato dos imóveis menores que 10 ha, extrato denominado criticamente por Mitidiero Junior, Barbosa e Hérick de Sá (2017) como "quase pequenos": em 1985, eram $50,76 \%$ do número de imóveis total e ocupavam apenas $5,26 \%$ da superfície agrícola; em 2014, aumentam para 56,94\%, "espremidos" em 6,58\% dessa superfície. Os gráficos 1 e 2 nos ajudam a visualizar essa dinâmica descrita.

$17.495 ; 36 \%$

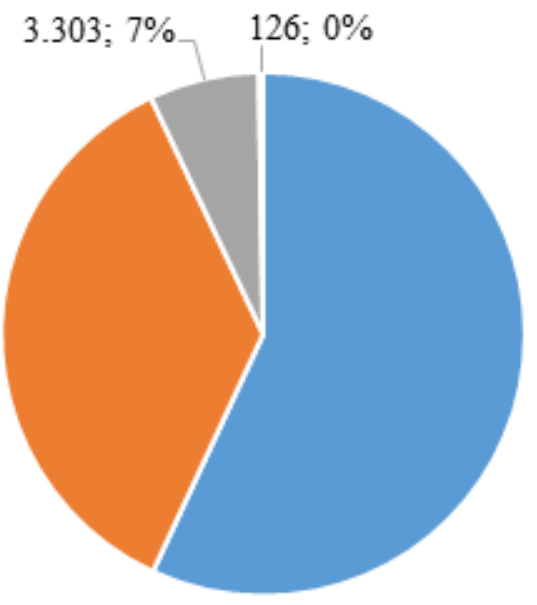

$27.668 ; 57 \%$

- Menos de $10 \quad=10<100 \quad \| 100<1000 \quad$ " Mais de 1000 


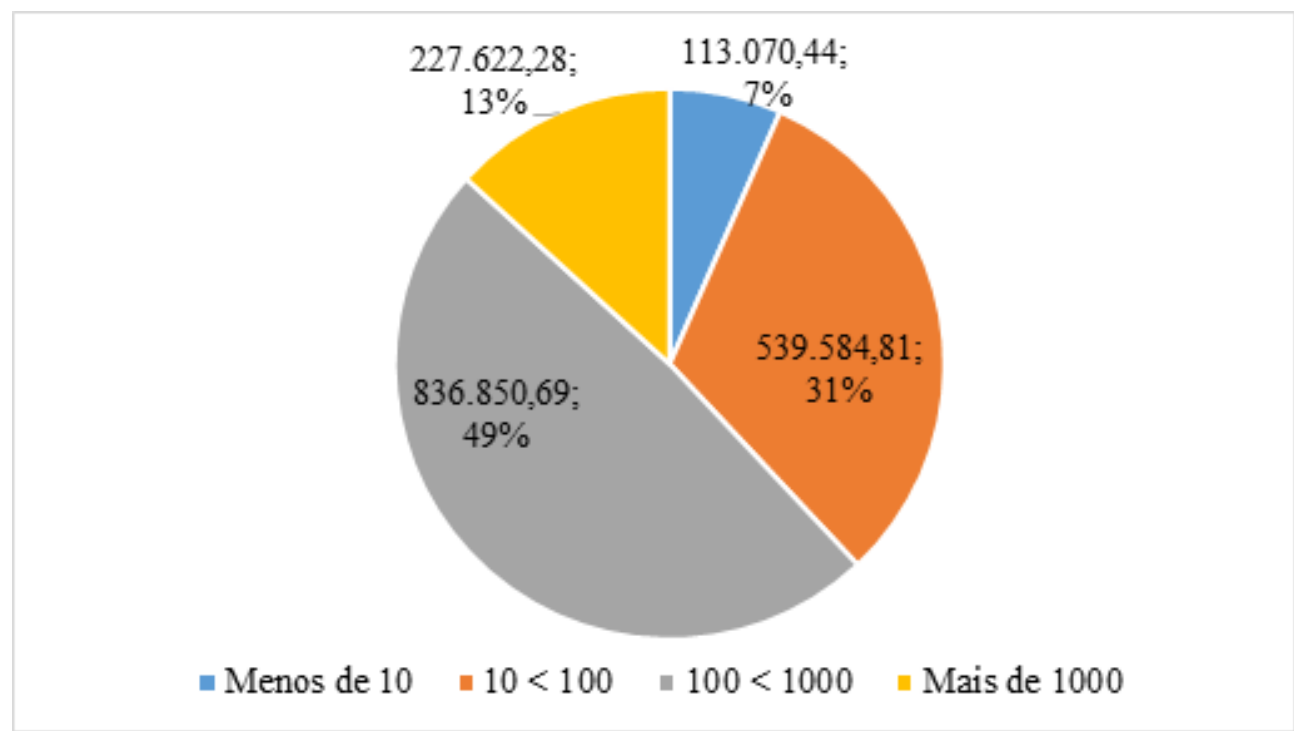

Fonte: INCRA (2017). Organização: Claudemir Martins Cosme.

Sobre esses dados do INCRA, declarados pelos próprios proprietários, três questões são importantes e devem ser mencionadas: a primeira é que precisa ser lembrada a estratégia de fatiar os latifúndios entre os herdeiros, ou seja, a artimanha dos latifundiários de se refugiarem em extratos médios através da fragmentação da grande propriedade rural e, assim, esconder a concentração fundiária, destacada por Ramos Filho e Ramos (2014) em estudo sobre o estado de Sergipe. Como destaca o gráfico acima, há uma forte presença dos extratos médios na apropriação do território - os imóveis rurais entre 100 e 1000 ha -, com $6,8 \%$ do total geral, possuem quase $50 \%$ da área total. Essa constatação alimenta a hipótese de que fatiar imóveis rurais, tudo indica, tem sido uma prática eficaz em Alagoas, fato que pretendemos aprofundar e demonstrar em futuras pesquisas. A segunda questão é que a concentração da terra sempre tende a ser maior do que demonstram os dados oficiais. Remetemo-nos ao caso, por exemplo, de quando um mesmo usineiro/usina possui vários imóveis rurais sob seu controle.

A terceira questão é o fato de os dados oficiais apresentarem o que o próprio órgão denomina de "imóveis rurais inconsistentes excluídos" (INCRA, 2014). No Brasil, em 2014, eram 266.277 imóveis rurais nesse enquadramento, em uma área de pouco mais de 4,6 milhões de ha. Já em Alagoas, os registros são de 3.987 imóveis nessa situação, com uma área de 224.871,78 ha naquele ano. Estes não são contabilizados nem enquadrados nos extratos pelo SNCR/INCRA. De quem são essas terras? São terras devolutas? Estão ocupadas? Perguntas que ficam no ar para outras pesquisas/ pesquisadores.

Estudos de Oliveira (2010) sobre as terras devolutas no Brasil, cercadas ilegalmente pelos grandes proprietários grileiros, são pistas hipotéticas para respostas às questões suscitadas, pois o estado de Alagoas é aquele, dentre as Unidades da Federação, que apresentaria o maior percentual de suas terras enquadradas como devolutas: em torno de $36 \%$ do total do seu território, afirma o autor. É a realidade do campo alagoano corroborando os escritos de Marx (2013) sobre o processo de acumulação primitiva, no caso, o roubo de terras. Como enalteceu Mitidiero Junior e Feliciano (2018), essa é a forma da acumulação primitiva, que tanto serve para criar novos capitais, como para se apropriar de frações do território - muitas vezes já ocupadas pelo campesinato, povos indígenas e quilombolas, ocasionando expulsões, expropriações, saques e assassinatos -, bem como para absorver capital sobreacumulado na economia, oriundo de especulação e corrupção.

Aprofundando um pouco mais a análise dos dados oficiais (INCRA, 2014), a partir da malha fundiária dos municípios, destacamos que, entre os 126 grandes imóveis, temos três latifúndios no extrato de área entre 5.000 a menos de 10.001 ha, somando juntos $21.792,10$ 
ha. Todos são localizados na Mesorregião do Leste Alagoano, historicamente, o reduto da monocultora de cana-de-açúcar: um no município de Coruripe, com 8.743,10 ha; outro em Messias, com 6.049,00 ha; e o último em São Miguel dos Campos, com 7.000 ha. Encontramos também quinze com área no intervalo de 2.500 a menos de 5.001 ha, os quais somam $50.017,75$ ha. Dos quinze, treze se situam na referida mesorregião, e dois, na Mesorregião do Agreste. Já as grandes propriedades, com extratos de áreas entre 1.000 e 2.001 ha, somam 91. Dez destas se localizam na Mesorregião do Sertão Alagoano: os municípios de Água Branca e Delmiro Gouveia com três cada; Belo Monte, Piranhas, Olho D'água do Casado e Major Isidoro, com um imóvel cada. No Agreste, há apenas cinco propriedades. Mais uma vez, o Leste mostra que é o lócus da concentração fundiária, com 76 dos 91 imóveis (Mapa 1).

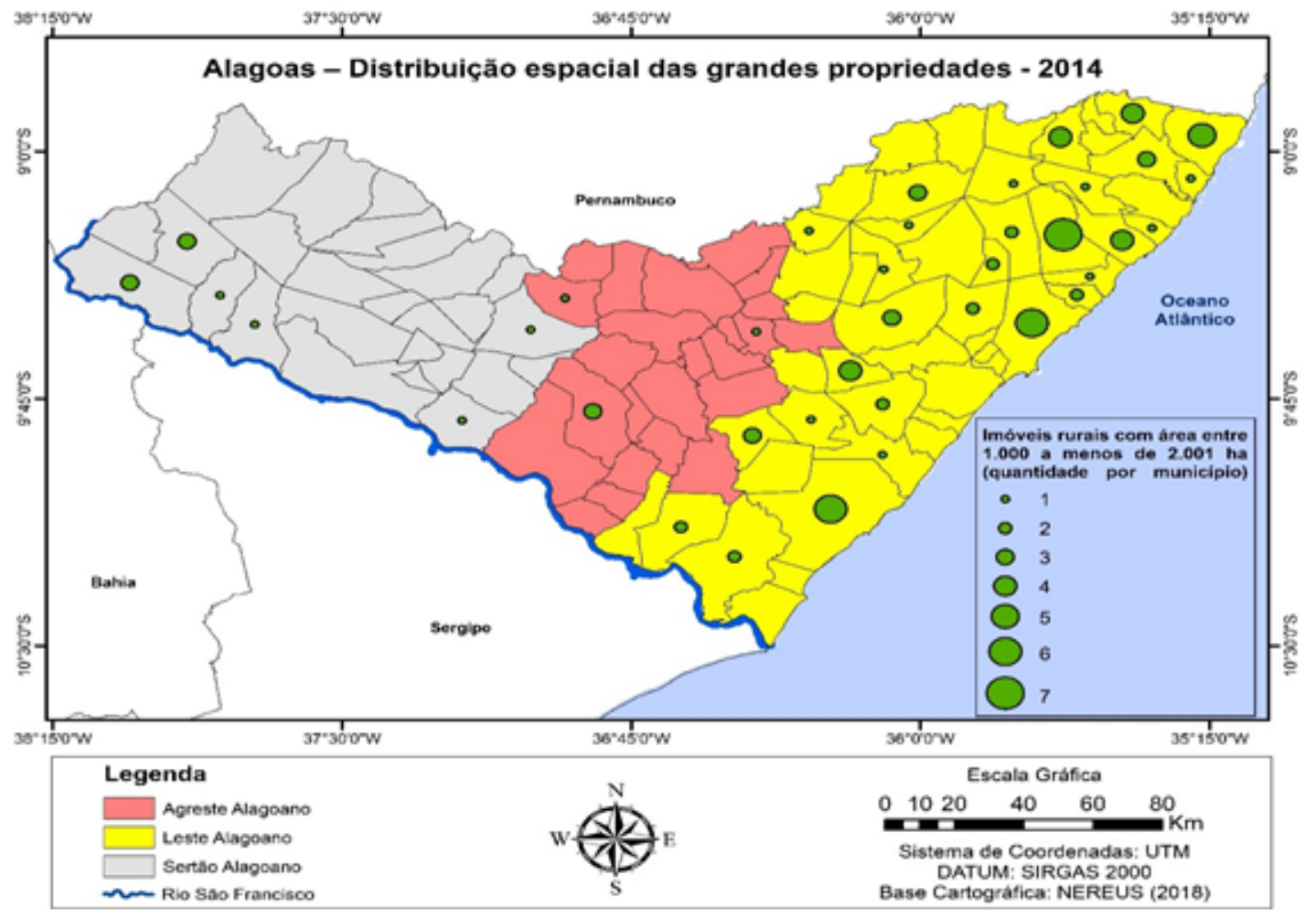

Fonte: INCRA (2014).

Portanto, a concentração fundiária, com a presença marcante do latifúndio, é uma marca no território alagoano do século $\mathrm{XXI}$, notadamente na região canavieira, enquanto o agreste e o sertão são espaços agrários onde predomina o minifúndio. Assim, dentre os três espaços mesorregionais que compõem o território desse estado, o Sertão, o Agreste e o Leste (litoral), foi neste último onde se materializou, mais fortemente, a "aliança do atraso" (MARTINS, 1999) entre o capital e a terra sob o aval do Estado. O latifúndio é, por conseguinte, uma marca colonial territorializada com muito mais intensidade no espaço agrário da Mesorregião do Leste alagoano (ALBUQUERQUE, 2016; LESSA, 2013; LINDOSO, 2000).

Essa presença estrutural do latifúndio canavieiro no Leste e, consequentemente, da profunda concentração da propriedade da terra em pouquíssimas mãos conformou "uma sociedade aristocrata, baseada no latifúndio agrícola e escravocrata. Isto significa uma sociedade mais rica e mais cruel" (LINDOSO, 2000, p. 37). No entanto, Albuquerque (2016) alerta que não se deve crer que o semiárido alagoano seja exemplo de justiça social, bem como alerta que foi devido às lutas sociais - desde as dos indígenas e quilombolas, passando na 
atualidade também pelas do campesinato Sem Terra - o fato de termos essa fração do território alagoano com uma apropriação menos desigual da terra, portanto, uma estrutura fundiária menos concentrada. Trataremos no próximo item, sumariamente, da luta contemporânea de uma fração do campesinato alagoano, no caso das famílias, antes Sem Terra, hoje assentadas nos assentamentos rurais conquistados.

0 enfrentamento entre o campesinato Sem Terra e as oligarquias latifundiárias: resistências e conquistas camponesas em meio à violência e à barbárie

Parafraseando Carvalho (2014), o culto apologético ao agronegócio, junto com a histórica lógica, dominante ainda hoje, da negação explícita do campesinato, acentuou as concepções e ações governamentais de contrarreforma agrária, ou seja, há uma espécie de sacralização do agronegócio a qualquer custo, presente de forma indelével na concepção de mundo dominante na sociedade brasileira, em que a preservação da estrutura fundiária intacta é uma das consequências. A contrarreforma agrária no Brasil, especialmente em Alagoas, (re)produz o latifúndio e o minifúndio. Enquanto isso, como diz Oliveira (2007), no campo e na cidade, diuturnamente, presenciamos a rebeldia camponesa na construção do seu próprio futuro.

Assim, os conflitos territoriais, protagonizados pelo campesinato Sem Terra - moradores de condição, meeiros, arrendatários, entre outros -, brotaram no campo alagoano em fins da década de 1980 e, especialmente, intensificaram-se a partir dos anos 1990, com o campesinato Sem Terra "mobilizado socialmente" e agindo por "desobediência civil" na maioria dos processos, nos termos de Gohn (2014). Remetemo-nos às ocupações/acampamentos, processos esses de resistência camponesa organizados, inicialmente, pelo Movimento dos Trabalhadores Rurais Sem Terra (MST/ $A L)$ e, em seguida, pela CPT/AL e por outros movimentose organizações sociais do campo, passando a influenciar a dinâmica da formação da estrutura fundiária em Alagoas. Não conseguiu alterá-la estruturalmente, é verdade, mas impediu seu avanço e até diminuiu a desigualdade do acesso à terra, de sua posse e propriedade.

Como afirma Fernandes (2010, p. 173), "a luta camponesa pela terra é territorial, pois a conquista de um latifúndio e sua transformação em assentamento rural promove mudanças na estrutura fundiária", bem como "o acesso à terra é condição essencial para o campesinato, pois é nesta que os camponeses [e camponesas] asseguram seu meio de existência, constroem sua identidade e reproduzem seu trabalho familiar" (Ibidem, p. 174). Nessa linha, Neves (1997, p. 421) assevera que os assentamentos rurais são conquistas que não podem passar despercebidas: "[...] num país onde a proposta de desconcentração da propriedade da terra é inadmissível para os proprietários diretamente interessados em preservar seus privilégios. $E$ também não é assimilável por outros segmentos enquanto proposta de construção da sociedade".

Os caminhos dessa conquista da fração da classe camponesa alagoana não se deram sem conflitos, sem violências vindas da classe dos proprietários capitalistas da terra. Foi se chocando, enfrentando, atravessando, literalmente, o ethos político-hegemônico das oligarquias burguesas latifundistas nesse estado que o campesinato, mobilizado nos movimentos e organizações sociais, conquistou os 178 assentamentos rurais, cujas frações territoriais, juntas, somam 113.985,37 ha, com 13.017 famílias assentadas nas três mesorregiões desse estado (INCRA, 2017). Como escreveu Almeida et al. (2014, p. 115), sobre esse processo, "o fundamental é que estamos diante de uma contestação radical à forma estruturada do agrarismo alagoano, formada desde as raízes coloniais, na qual o poder - de mando e desmando - fundou-se na propriedade da terra".

A espacialização desse enfrentamento radical do campesinato Sem Terra contra os latifundiários resultou no seguinte quadro: a Mesorregião do Leste Alagoano (zona da mata e litoral), que concentra a maior parte dos conflitos territoriais e a barbárie (assassinatos) levada a cabo pelos usineiros, é, justamente, aquela que também concentra sozinha ampla parte das conquistas dos movimentos - $65,73 \%$ (117) do total geral dos assentamentos -, seguida pela Mesorregião do Sertão, com 23,03\% (41), e pelo, Agreste com 9,33\% (20). No tocante à quantidade de famílias assentadas atualmente, seguindo a tendência do número de assentamentos, temos a Mesorregião do Leste Alagoano como a que concentra sozinha 10.350 ou $79,51 \%$ do total geral, seguida pela Mesorregião do Sertão, com 1.474 ou $11,32 \%$, e pelo Agreste, com 1.193 ou $9,16 \%$ (INCRA, 2017). Dos $113.985,37$ ha, $66,40 \%$ ( $75.68,74$ ha) estão no Leste; $21,04 \%(23.978,11)$, no sertão; e 12,56 (14.320,52), no Agreste (Ver Mapa 2). 


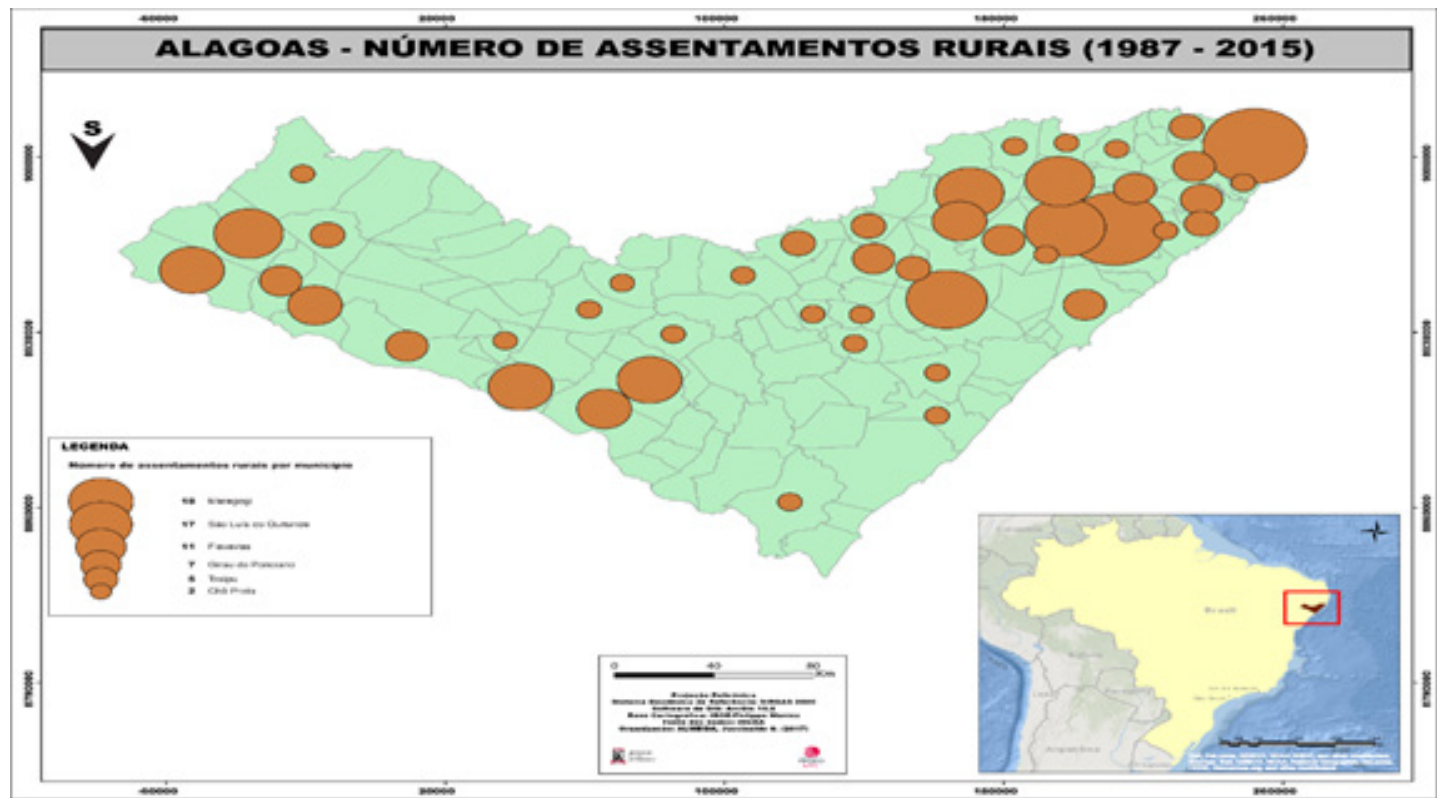

Fonte: INCRA (2014).

É preciso dar ênfase ao pensamento de Albuquerque (2016), que, ao tratar da presença camponesa no espaço agrário alagoano, afirma: "o latifúndio nem sempre abriu os caminhos, muitas vezes sua afirmação ocorreu pelo combate e encurralamento da cultura campesina". Segundo ele, o campesinato alagoano, que tem suas raízes construídas no período colonial, sempre lutou tenazmente contra um modelo totalizante de sociedade, representado pelo latifúndio, que historicamente avança sobre suas terras. São as visões sociais de mundo antagônicas, no caso aqui em análise, entre o campesinato assentado e a burguesia latifundista, representante das oligarquias locais, donos do poder, do capital e da propriedade privada capitalista da terra, que fomentam a contradição entre os diferentes regimes de propriedade, influenciando a dinâmica de formação da estrutura fundiária desse estado, historicamente marcada por profundos conflitos territoriais.

São enfrentamentos movidos por territorialidades distintas que compreendem a propriedade da terra, as relações sociais de poder e com a natureza, a partir de ângulos que se contrapõem: é o embate entre a terra de negócio/mercantil e a terra de trabalho/terra bem social (MARTINS, 1991; DELGADO, 2017). Portanto, a estrutura fundiária veio sendo constituída ao longo da formação territorial brasileira e alagoana no bojo do capitalismo, que "internaliza práticas tanto canibais como predatórias e fraudulentas" (HARVEY, 2013, p. 124). Destarte, a violência e a barbárie praticadas pelos grandes proprietários contra os diversos sujeitos/sujeitas em luta no campo alagoano, repetindo Marx (2013), "está gravada em traços de sangue e fogo".

Lindoso (2000, p. 170) defende que a violência se fez parte estrutural na origem e constituição da sociedade alagoana, da geral à mais íntima das relações: "quaisquer das formas de controle social exigiam o emprego organizado da violência". Prova dessa permanência no século XXI é que, entre 1985 e 2017, segundo consta nos relatórios Conflitos no Campo Brasil, da Comissão Pastoral da Terra, ocorreram 24 assassinatos, 37 tentativas de assassinato e 52 ameaças de morte (CPT, 1985-2017), ceifando e/ou ameaçando a vida de lideranças camponesas, indígenas e quilombolas, bem como de militantes e lideranças dos movimentos e organizações sociais que apoiam a luta e a resistência camponesa em Alagoas. 0 gráfico 3 faz emergir essa face perversa da questão (da reforma) agrária brasileira ano a ano. Entre 1985 e 2016, somente nos anos de 1985, 1986, 1990, 1998, 2011 e 2015, não constam registros de pelo menos um desses três processos no estado: assassinatos, tentativas de assassinatos e ameaças de morte. Os anos mais violentos foram os marcados pelos assassinatos: 1997, 1999 e 2016, com 2 vidas retiradas em cada ano e, em 1994, com 3 assassinatos. 


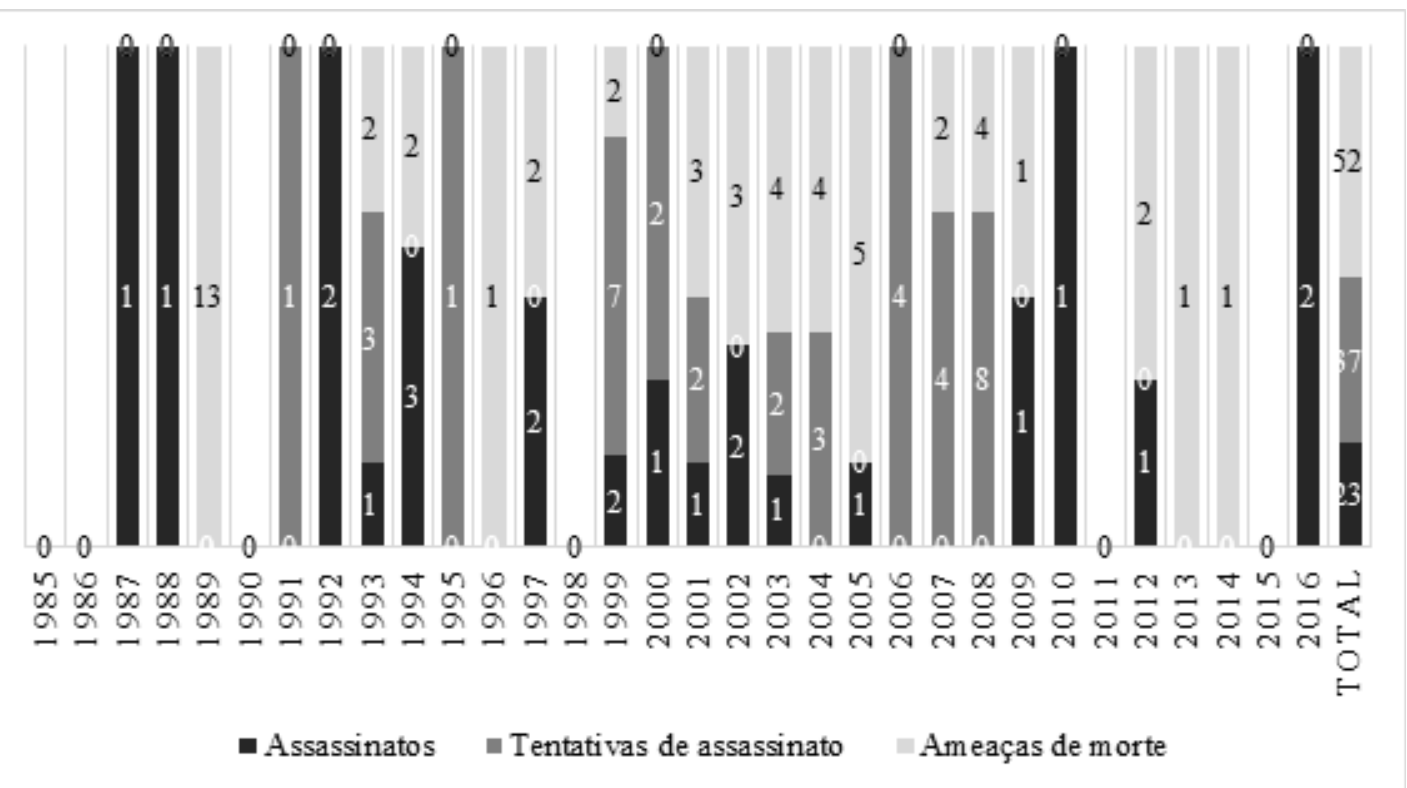

Fonte: CPT (1985 - 2017). Organização: Claudemir Martins Cosme.

O quadro geral da violência no campo no estado de Alagoas, em termos espaciais, é o seguinte: no tocante aos assassinatos, $79,16 \%$ (19) ocorreram na Mesorregião do Leste Alagoano e 20,83\% (4) na Mesorregião do Agreste, sem registros na Mesorregião do Sertão Alagoano. Isso prova que, quanto mais concentrada é a terra, no caso da região monocultora da cana, maior é a violência dos latifundiários e maiores são os desafios e, consequentemente, a necessidade de resistência e mobilização social camponesa. 0 mapa 3 ajuda na percepção da concentração dos assassinatos na região canavieira, berço do latifúndio monocultor da cana-deaçúcar. É a contrarreforma agrária "na marra", como destaca Porto-Gonçalves e Alentejano (2011), ou seja, a barbárie utilizada pelos usineiros contra o campesinato Sem Terra, que enfrenta o centro do poder oligárquico nesse estado: o latifúndio e as oligarquias da cana.

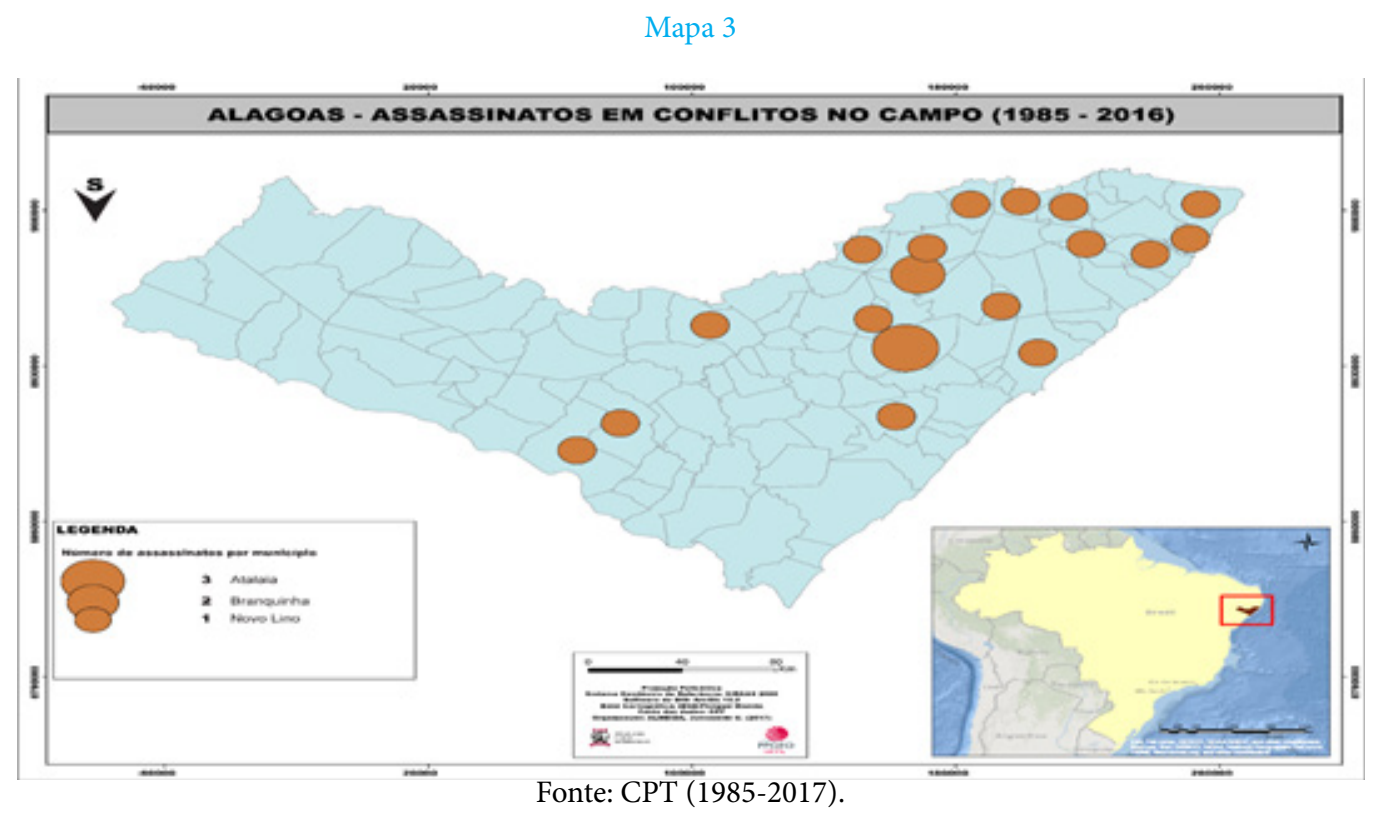

Já com relação às 37 tentativas de assassinato, temos a seguinte distribuição: mais uma vez o predomínio no Leste, com 59,46\% (22); 32,43\% (12) no sertão e $8,11 \%$ (3) no Agreste. No tocante às ameaças de mortes, 57,69 (30) do total geral ocorreram na Mesorregião do Leste Alagoano, ficando o Agreste com 30,77\% (16) e o Sertão com 11,54\% (6) (ver mapas 4 e 5). 0 espaço agrário do agronegócio latifundiário-canavieiro, em Alagoas, definitivamente, é o mais violento no estado, fortalecendo as palavras de Oliveira (2007) de que a barbárie é a face cruel da modernidade no Brasil. 


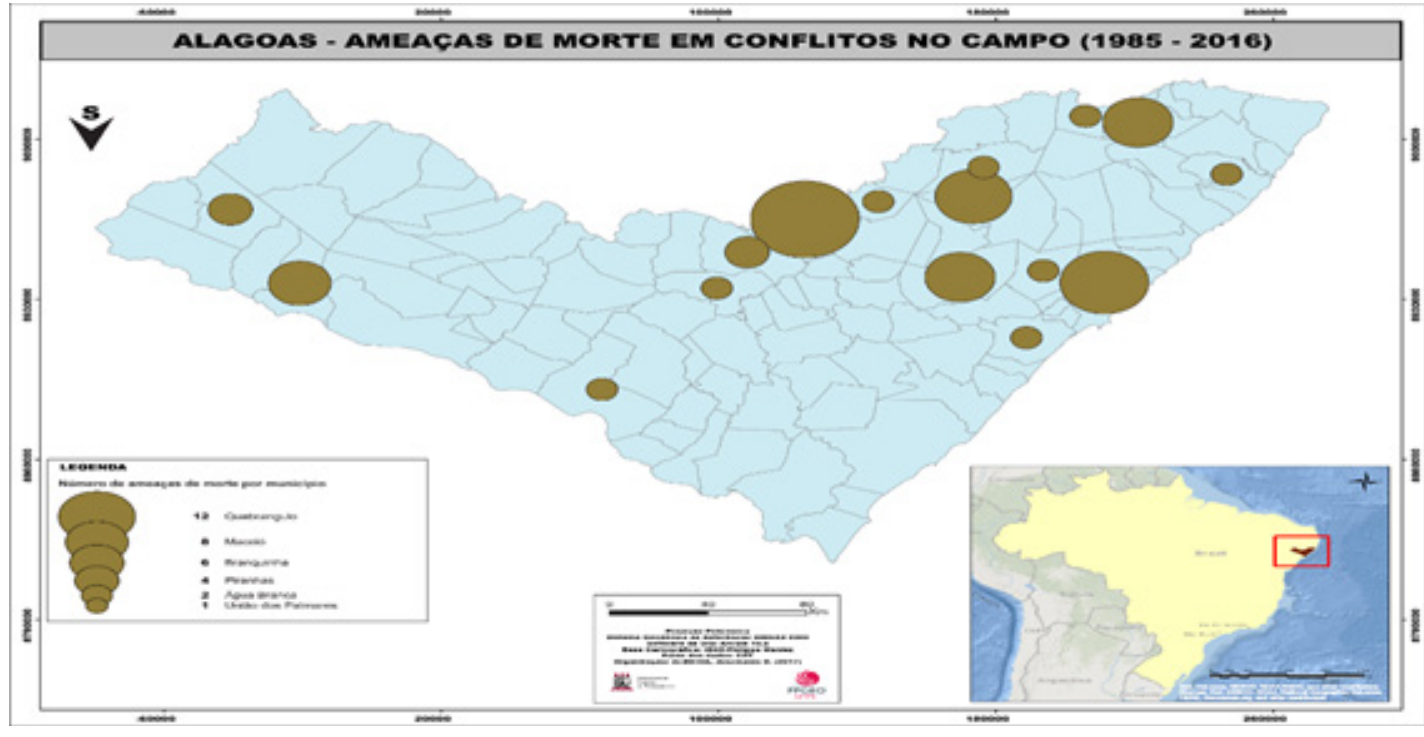

Fonte: CPT (1985-2017).

Mapa 5

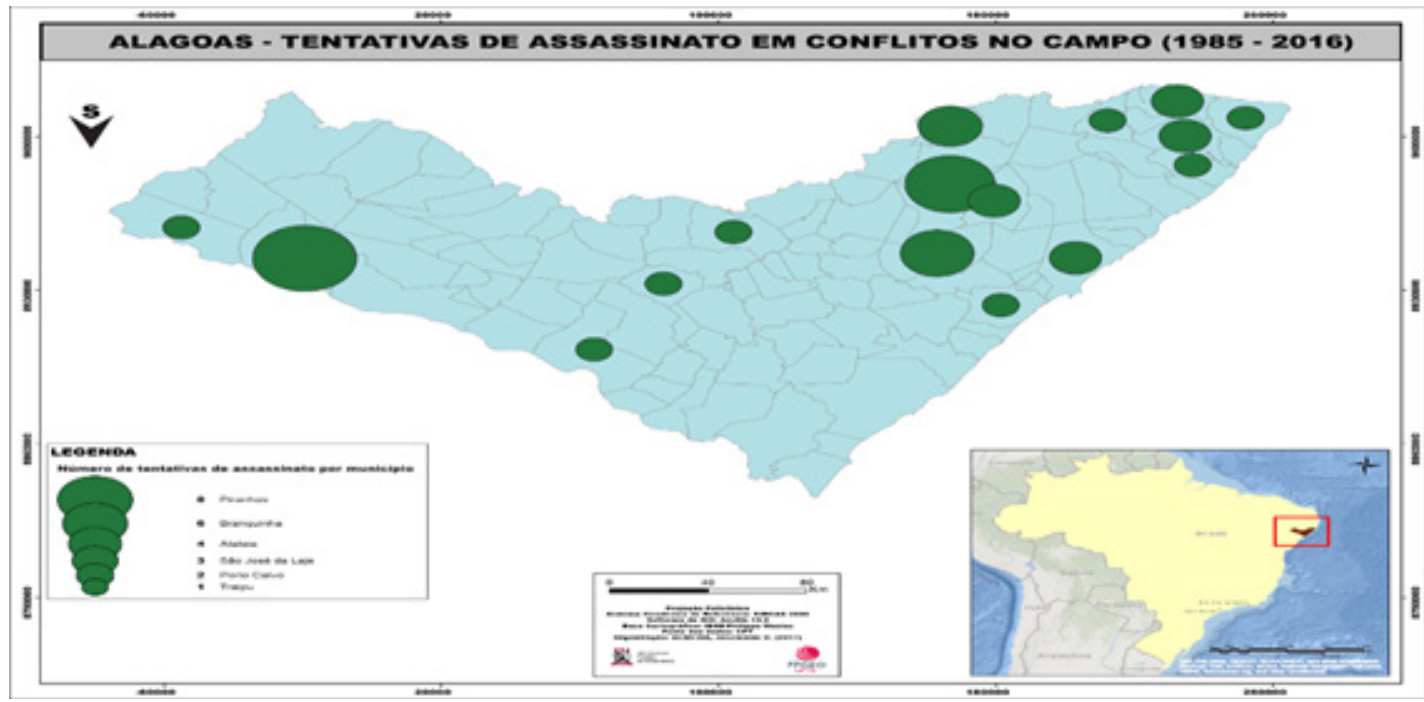

Fonte: CPT (1985-2017).

Frente a esse contexto conflituoso do campo alagoano nas últimas décadas, é mister recordarmos as palavras de Almeida (2010, p. 11), que, ao tratar dos(as) sujeitos(as) Sem Terra em luta pela terra nesse estado, assevera que estamos diante da relação de classe no agrário, onde "[...] o semterra ${ }^{2}$ perpassa classificações de setor produtivo e responde por todos aqueles que, em movimento, assumem posição política na qual a terra tem o sentido de libertação, que não pode ser esvaziado no [processo] de posse [da terra]". Continua o autor: "A resolução do semterra não é o surgimento do comterra, pois equivaleria a afirmar que ter a propriedade define a questão: ela é habilitante e somente habilitante" (Idem).

$O$ debate da posse da terra como condição habilitante para que o campesinato Sem Terra lute pela liberdade é um debate - ou melhor, uma luta - que passa pela alteração da estrutura fundiária. Portanto, a liberdade camponesa e o acesso à terra são temáticas inseparáveis que afetam diretamente o cerne do poder em Alagoas, fundado na concentração da propriedade privada capitalista da terra. Por isso, tamanha é a violência e a barbárie com que é recebido o campesinato que levanta a bandeira da reforma agrária, levadas a cabo pelas oligarquias agrárias alagoanas.

Entrementes, apesar de a centralidade desse estudo ser a estrutura fundiária ancorada no antagonismo entre os regimes de propriedade privada - o capitalista e o do campesinato, este a partir das famílias assentadas -, não podemos deixar invisibilizada a presença das terras de uso comum em Alagoas, que, historicamente, foram conquistas de resistências profundas e diversas dos 
povos originários contra a expropriação e a violência eque, portanto, contribuíram/contribuem até hoje para atenuar a elevada concentração fundiária no território alagoano. Dados oficiais apontam a existência de doze terras indígenas com uma área total de aproximadamente 27 mil ha (FUNAI, 2016) e de 68 comunidades quilombolas certificadas pela Fundação Cultural Palmares (FCP, 2019). Trata-se de uma temática - as terras de uso comum - que precisa de pesquisas aprofundadas sobre a realidade no campo alagoano.

\section{Considerações finais}

A contrarreforma agrária à brasileira tem, na perpetuação da estrutura fundiária, profundamente concentrada, a sua principal face, entre muitas outras. Na lei ou na "marra", através de violências e da barbárie, as forças contrarreformistas têm impedido a realização da reforma agrária no país. 0 campo alagoano não foge à regra. A concentração da propriedade da terra em extensos latifúndios de um lado e o profundo processo de minifundização de outro são marcas desse espaço agrário, onde as oligarquias latifundistas perpetuaramse no poder e comandam as relações sociais de poder nesse território, a partir da propriedade privada capitalista da terra.

Assim, a centralidade da questão agrária, mais do que nunca, está na contradição entre dois regimes diferentes e antagônicos de propriedade privada da terra: a propriedade privada capitalista, fundada na exploração do trabalho alheio e na subordinação camponesa; e a propriedade privada ancorada no trabalho próprio, familiar, a partir da unidade de produção camponesa, sem exploração do trabalho e sem dinâmica de (re)produção voltada para o lucro capitalista. Assim, a manutenção e o avanço da burguesia latifundista, responsáveis pela terra de negócio ou terra mercantil, concomitantemente, sempre encontrou a resistência da classe camponesa, que se apropria da terra enquanto um bem comum da natureza. Tal apropriação é legitimada pelo trabalho familiar, e não pela exploração do trabalho assalariado. Essa contradição carrega em seu cerne territorialidades opostas, que têm influenciado na dinâmica da estrutura agrária no Brasil, não sendo diferente em Alagoas.

Como vimos, quando a análise tem por base a forma como está distribuída espacialmente a posse, uso e propriedade da terra, percebemos pelo menos duas Alagoas, territorialmente bem demarcadas e imbricadas: 1) as Mesorregiões do Sertão e do Agreste, com um espaço agrário menos desigual, mas com problemas estruturais ainda, devido à presença marcante do minifúndio, como também, em menor grau, do latifúndio;
2) a Mesorregião do Leste Alagoano, reverso das anteriores, ou seja, profundamente hierarquizada e antidemocrática, reduto do latifúndio monocultor canavieiro. Nesse fragmento territorial, impera a vontade dos donos da terra, do capital e do poder político, unificado, primordialmente, no mesmo sujeito social: o usineiro. É nesse espaço que se concentra a maior parte das violências e barbáries sofridas pelos que hasteiam a bandeira da reforma agrária e lutam pela terra e pelo território de vida, produzido pelo e para o campesinato, bem como pelo e para os diversos sujeitos(as)/grupos sociais do campo.

A conquista de quase duas centenas de assentamentos rurais é uma vitória para o campesinato alagoano, mesmo estando ainda longe de caracterizar uma reforma agrária. 0 Índice de Gini não deixa dúvidas sobre esse processo: de um coeficiente de 0,858 em 1985, atinge 0,863 em 1995 e, em 2006, chega a 0,871 (IBGE, 2006), marcando Alagoas como o estado com a maior concentração de terra entre todas as Unidades da Federação. A permanência da concentração fundiária e, consequentemente, da violência e da barbárie desautorizam as leituras que pregam que houve ou que está em curso uma reforma agrária no país.

Entretanto, a conquista de frações territoriais pelo campesinato é condição sine qua non para garantia de sua existência social. Daí, o tamanho de sua importância. Por isso, afirmamos que os assentamentos rurais são conquistas do campesinato Sem Terra. Acrescentamos, todavia, que, sem um amplo processo de reforma agrária, que altere a estrutura fundiária, elimine o latifúndio e o modelo agrário/agrícola fundado no agronegócio em favor do campesinato, essas conquistas permanecem sob risco, e a sociedade, em geral, sofre uma grande derrota. Assim, a reforma agrária ainda é uma política a ser realizada no Brasil e depende, para que haja ação propositiva do Estado e dos governos em prol de sua realização, da mobilização social dos movimentos e organizações sociais do campo e da cidade. 


\section{Referências}

ALBUQUERQUE, Cícero Ferreira de. (2016) Camponeses e canavieiros: razões e significados da migração do Semiárido para a zona da mata alagoana. 228f. Tese (Doutorado em Ciências Sociais). Universidade Federal de Campina Grande, Campina Grande, PB. Disponível em: http://dspace.sti.ufcg.edu.br:8080/jspui/handle/riufcg/158. Acesso em 28 dez. 2017.

ALENTEJANO, Paulo. (2018) A política agrária do governo Temer: a pá de cal na agonizante reforma agrária brasileira? Revista Okara, João Pessoa, v. 12, n. 12, p. 308-325. Disponível em:http://www.periodicos.ufpb.br/ojs/index.php/okara/article/view/41319/20719. Acesso em: 27 set. 2018.

ALMEIDA, Luiz Sávio et. al (Orgs.). (2014) Terra e Pastoral em Alagoas: conflito e liberdade. Maceió: EDUFAL.

(2010) Manuel Correia de Andrade: os empobrecidos e a terra. Economia política do desenvolvimento. Maceió, vol. 3, Edição Especial, p. 9-44, ago. 2010. Disponível em:http://www.seer.ufal.br/index.php/repd/article/view/149. Acesso em: 10 mar. 2018.

ALMEIDA, Rosemeire Aparecida de. (2006) (Re)criação do campesinato, identidade e distinção: a luta pela terra e o habitus de classe. São Paulo: Editora da Unesp.

BOFF, Leonardo. (2017) Conflitos no campo, suas causas e possíveis saídas. In. CPT. Conflitos no Campo - Brasil 2016. Goiânia: CPT Nacional - Brasil, pp. 120-131. Disponível em: https://www.cptnacional.org.br/index.php/component/ jdownloads/download/41-conflitos-no-campo-brasil-publicacao/14061-conflitos-no-campo-brasil-2016. Acesso em: 20 dez. 2017.

CARVALHO, Horácio Martins de. (2014) A contra reforma agrária e o aumento das desigualdades sociais. In. ABRA. Questão agrária e desigualdades no Brasil. Reforma Agrária, São Paulo, v. 1, n. 2.

O campesinato contemporâneo como modo de produção e como classe social. (2012) Boletim DataLuta - artigo do mês de maio, Presidente Prudente: Núcleo de Estudos, Pesquisas e Projetos de Reforma Agrária. Disponível em: www.fct.unesp.br/nera. Acesso em: 24 jan. 2018.

COSME, Claudemir Martins. (2017) Luta camponesa, indígena e quilombola face à barbárie do agronegócio no Brasil: a contrarreforma agrária se aprofunda em tempos-espaços de golpe. In. CPT. Conflitos no Campo Brasil 2017. Goiânia: CPT.

(2016) Reforma agrária no Brasil do século XXI: qual reforma agrária? Boletim DATALUTA, outubro, 2016a, p. 1-25. Disponível em:http://www2.fct.unesp.br/nera/artigodomes/10artigodomes_2016.pdf. Acesso em: 20 mar. 2018.

. (2016b) Os governos do PT e os descaminhos com a questão agrária no Brasil: contribuições para um diálogo polêmico, necessário e imprescindível à classe trabalhadora. Revista Pegada. Presidente Prudente, v. 4, n. 1. Disponível em: http://revista.fct.unesp.br/index.php/pegada/article/view/4467. Acesso em: 20 mar. 2017.

(2015) A expulsão de camponeses assentados como uma das faces da contrarreforma agrária no Brasil: um estudo da evasão nos assentamentos rurais do Ceará. Dissertação de Mestrado, Programa de Pós-Graduação em Geografia, Universidade Federal da Paraíba.

CPT. Comissão Pastoral da Terra.(2018) Conflitos no Campo - Brasil. Goiânia, 1985 - 2017. Disponível em: http://www. cptnacional.org.br. Acesso em: 07 ago. 2018.

DELGADO, Guilherme. (2017) A questão agrária hoje. In. MATTEI, Lauro (Org.). Reforma agrária no Brasil: trajetória e dilemas. Florianópolis: Insular.

FERNANDES, Bernardo Mançano. (2017) Questões teóricas e políticas de um governo em disputa: a reforma agrária no governo Dilma. In. MATTEI, Lauro (Org.). Reforma agrária no Brasil: trajetória e dilemas. Florianópolis: Insular.

. (2013) A reforma agrária que o governo Lula fez e a que pode ser feita. In. SADER, Emir (Org.). 10 anos de governos pós-neoliberais no Brasil: Lula e Dilma. São Paulo: Boitempo; Rio de Janeiro: FLACSO Brasil, p. 191-205.

. (2010) Formação e Territorialização do MST no Brasil. In: CARTER, Miguel. (org.). Combatendo a desigualdade social: o MST e a reforma agrária no Brasil. São Paulo: UNESP, p. 161 - 198.

Fundação Cultural Palmares (FCP). (2019) Comunidades Certificadas em Alagoas. Brasília. Disponível em:http://www. palmares.gov.br/sites/mapa/crqs-estados/crqs-al-02082019.pdf. Acesso em: 14 de out. 2019.

Fundação Nacional do Índio (FUNAI). (2006) Terras Indígenas em Alagoas.Brasilia. Disponível em: http://www.funai. gov.br/index.php/indios-no-brasil/terras-indigenas. Acesso em: 14 de out. 2019. 
GARCÍA, Antonio. (1970) Dinámica de las reformas agrarias en América Latina. 3 ed. Medellin/Bogotá: Editorial La Oveja Negra, Bogotá.

GOHN, Maria da Glória. (2014) Novas teorias dos movimentos sociais. São Paulo: Edições Loyola.

HARVEY, David. (2013) O novo imperialismo. São Paulo: Loyola.

IANNI, Octávio. (1979) Colonização e contra-reforma agrária na Amazônia. Petrópolis: Vozes.

IBGE, Instituto Brasileiro de Geografia e Estatística. (2006) Tabela 10 - Evolução do Índice de Gini, segundo as Unidades da Federação - 1985/2006. Disponível em: https://ww2.ibge.gov.br/home/estatistica/economia/agropecuaria/ censoagro/brasil_2006/tab_brasil/tab10.pdf. Acesso em: 22 dez. 2018.

INCRA, Instituto Nacional de Colonização e Reforma Agrária. (2017) Projetos de reforma agrária conforme fases de implementação: período de criação do projeto: 01/01/1970 até 06/03/2017. Maceió. Pendrive.

Cadastro de Imóveis Rurais - Situação Jurídica - Titularidade Particular - 2014. Brasília,2014.

Cadastro de Imóveis Rurais 1985. Brasília, 1985.

LESSA, Golbery Luiz. (2013) Por um programa agrário para a esquerda alagoana. In. ALMEIDA, Luiz Sávio de; LIMA, José Carlos da Silva; OLIVEIRA, Josival dos Santos (Orgs.). Terra em Alagoas: temas e problemas. Maceió: EDUFAL.

(2012) A Estrutura Fundiária de Alagoas na segunda metade do século XX. Alagoas. Disponível em:http://pcbalagoas.blogspot.com.br/2012/01/artigoa-estrutura-fundiaria-de-alagoas.html. Acesso em: 15 dez. 2017.

LINDOSO, Dirceu. (2000) A formação de Alagoas Boreal. Maceió-São Paulo: Edições Catavento.

. (1983) A utopia armada: rebeliões de pobres nas matas do Tombo Real (1832 - 1850). Rio de Janeiro: Paz e Terra.

MARX, Karl. (2013) O Capital: crítica da economia política, livro I: o processo de produção do capital. São Paulo: Boitempo.

MARTINS, José de Souza. (1999) O poder do atraso: ensaios de sociologia da história lenta. 2. ed. São Paulo: Hucitec.

. (1991) Expropriação e violência: a questão política no campo. 3. ed. São Paulo: Hucitec.

(1981) Os camponeses e a política no Brasil: as lutas sociais no campo e seu lugar no processo político. 5 ed. Petrópolis: Vozes.

MEDEIROS, Leonilde Servolo de. (2014) Conflitos Fundiários e Violência no Campo. In. CPT. Conflitos no Campo Brasil 2014. Goiânia: CPT. Disponível em:https://cptnacional.org.br/publicacoes-2/conflitos-no-campo-brasil. Acesso em: 28 dez. 2018.

MITIDIERO JR., Marco Antonio; FELICIANO, Carlos Alberto. (2018) A violência no campo brasileiro em tempos de golpe e a acumulação primitiva de capital. Revista Okara, João Pessoa, v. 12, n. 12, p. 220-246. Disponível em:http://www. periodicos.ufpb.br/ojs2/index.php/okara/article/view/41315/20712. Acesso em: 27 set. 2018.

MITIDIERO JR., Marco Antonio; BARBOSA, Humberto Junior Neves; HÉRICK DE SÁ, Thiago. (2017) Quem produz comida para os brasileiros? 10 anos do Censo Agropecuário 2006. Pegada. Presidente Prudente, v. 18, n. 3. Disponível em: http://revista.fct.unesp.br/index.php/pegada/article/view/5540>. Acesso em: 20 mar. 2018.

MOREIRA, Emília; TARGINO, Ivan. (1997) Capítulos de Geografia Agrária da Paraíba. João Pessoa: Ed. Universidade Federal da Paraíba.

NEVES, Delma Pessanha. (1997) Assentamento rural: reforma agrária em migalhas. Niterói, EDUFF.

OLIVEIRA, Ariovaldo Umbelino de. (2015) Camponeses, indígenas e quilombolas em luta no campo: a barbárie aumenta. In. CPT. Conflitos no Campo Brasil 2015. Goiânia: CPT. Disponível em:https://cptnacional.org.br/publicacoes-2/ conflitos-no-campo-brasil. Acesso em: 28 dez. 2018.

(2010) A questão agrária no Brasil: não reforma agrária e contrarreforma agrária no governo Lula. In. MAGALHÂES, João Paulo de Almeida et al. Os anos Lula: contribuições para um balanço crítico 2003 -2010. Rio de Janeiro: Garamond.

. (2007) Modo capitalista de produção, agricultura e reforma agrária. São Paulo: FFLCH/Labur Edições.

(2001) A agricultura camponesa no Brasil. 4. ed. São Paulo: Contexto. 
OLIVEIRA, Francisco de. (2013) Crítica à razão dualista. São Paulo: Boitempo.

PORTO-GONÇALVES, Carlos Walter et al. (2015) Bye bye Brasil, aqui estamos: a reinvenção da questão agrária no Brasil. In. CPT. Conflitos no Campo Brasil 2015. Goiânia: CPT. Disponível em: https://cptnacional.org.br/publicacoes-2/conflitos-no-campo-brasil. Acesso em: 28 dez. 2018.

PORTO-GONÇALVES, Carlos Walter; ALENTEJANO, Paulo Roberto Raposo. (2011) A Contra-Reforma Agrária na Lei e na Marra. In. CPT. Conflitos no Campo Brasil 2010. Goiânia: CPT Nacional. Disponível em: https://cptnacional.org.br/ publicacoes-2/conflitos-no-campo-brasil. Acesso em: $28 \mathrm{dez} .2018$.

RAMOS FILHO, Eraldo da Silva. (2008) Questão agrária atual: Sergipe como referência para um estudo confrontativo das políticas de reforma agrária e reforma agrária de mercado (2003-2006). 410p. Tese (Doutorado em Geografia). Presidente Prudente. Disponível em: http://www4.fct.unesp.br/nera/biblioteca.php. Acesso em: 3 jan. 2014.

RAMOS FILHO, Eraldo da Silva; RAMOS, Oneclark Francisco. (2014) Concentração fundiária, monopolização do território camponês e mercados institucionais: desafios ao combate à pobreza em Sergipe. In: FAPITEC/SE. Pesquisa em políticas públicas no estado de Sergipe: Série Documentos 1. São Cristóvão: Editora da UFS, p. 161 - 187.

SAMPAIO Jr, Plínio de Arruda. (2017) Notas críticas sobre a atualidade e os desafios da questão agrária brasileira. In. MATTEI, Lauro (Org.). Reforma agrária no Brasil: trajetória e dilemas. Florianópolis: Insular.

SHANIN, Teodor. (1983) La clase incómoda: sociología política del campesinato em una sociedad em desarrollo (Rusia 1910 - 1925). Madrid: Alianza.

SILVA, José Gomes da. (1971) A reforma agrária no Brasil: frustação camponesa ou instrumento de desenvolvimento? Rio de Janeiro: Zahar Editores.

SOBREIRO FILHO, José; FERNANDES, B. M.; PEREIRA, D. V.; RAMOS FILHO, E. S.; LIMA, D. M. D. F.; IZA, L.; SILVA, F. A. (2018) O golpe na questão agrária brasileira: aspectos do avanço da segunda fase neoliberal no campo. Boletim DATALUTA, v. 1, p. 2-29. Disponível em:http://www2.fct.unesp.br/nera/boletimdataluta/boletim_dataluta_2_2018.pdf. Acesso em: 22 dez. 2018.

THOMAZ JÚNIOR, Antônio. (2003) Jogo de cena e poder de classe no Brasil do século XXI: a contra-reforma agrária no governo Lula. Revista Pegada. Presidente Prudente, v. 4, n. 1. Disponível em: http://revista.fct.unesp.br/index.php/ pegada/article/viewFile/819/841. Acesso em: 28 nov. 2018. 